\title{
STUDI PADA PENGENDALIAN MUTU PENDIDIKAN AGAMA ISLAM DI SMAN 1 LABUHAN HAJI LOMBOK TIMUR
}

\author{
Oleh: Nasri ${ }^{1}$ \\ STIT PALAPA NUSANTARA LOMBOK NTB
}

nasriazkia@gmail.com

\begin{abstract}
: none component of success in the world of education is the presence of teaching staff called teachers. The formation of religious values or religusitas is highly prioritized to increase the moral values and attitudes of students. So that the strategy to control the quality of Islamic education can be seen in the class control process developed by the quality development team.

School accountability is required to have accountability both to the community and the government. This is a combination of commitment to the standards of success and expectations or demands of parents and the community.

This accountability aims to ensure that public funds in supporting educational activities can be used in accordance with predetermined policies in order to improve the quality of education and if possible to provide information about what has been done. For that the school must provide accountability reports and communicate it to parents and the government, and carry out a comprehensive review of the implementation of the school's priority programs in Quality improvement. Islamic religious education is a structured effort to form human beings who have character in accordance with the consequences as a Muslim.
\end{abstract}

\footnotetext{
${ }^{1}$ Penulis adalah dosen STIT Palapa Nusan tara Lombok NTB 


\begin{abstract}
ABSTRAK
Salah satu komponen keberhasilan dalam dunia pendidikan adalah adanya tenaga pengajar yang disebut dengan guru. Pembentukan nilai-nilai keagamaan atau religusitas sangat diutamakan untuk meningkatkan nilai moral dan sikap siswa-siswi. Sehingga strategi pengendalian mutu pendidikan Islam dapat dilihat pada proses pengendalian kelas yang dikembangkan oleh tim pengembang mutu.

Pertanggung-jawaban (accountability) sekolah dituntut untuk memilki akuntabilitas baik kepada masyarakat maupun pemerintah. Hal ini merupakan perpaduan antara komitmen terhadap standar keberhasilan dan harapan atau tuntutan orang tua dan masyarakat. Pertanggung-jawaban (accountability) ini bertujuan untuk meyakinkan bahwa dana masyarakat dalam mendukung kegiatan pendidikan dapat dipergunakan sesuai dengan kebijakan yang telah ditentukan dalam rangka meningkatkan kualitas pendidikan dan jika mungkin untuk menyajikan informasi mengenai apa yang sudah dikerjakan. Untuk itu sekolah harus memberikan laporan pertanggung-jawaban dan mengkomunikasikannya kepada orang tua dan pemerintah, dan melaksanakan kaji ulang secara komprehensif terhadap pelaksanaan program prioritas sekolah dalam Peningkatan mutu .

Pendidikan agama Islam merupakan suatu upaya yang terstruktur untuk membentuk manusia yang berkarakter sesuai dengan konsekuensinya sebagai seorang muslim.
\end{abstract}

\title{
Kata Kunci : Pengendalian Mutu Pendidikan, Nilai-nilai Keagamaan
}

\section{PENDAHULUAN}

Dalam undang -undang dasar 1945 berkaiatan dengan pemberdayaan sumber daya manusia tersebut dala pasal 31 ayat 1 dan 2, yang berbunyi (1) tiaptiap warga negara berhak mendapatkan pendidikan dan pengajaran, (2) pemerintah mengusahakan dan menyelenggarakan satu sistem pendidikan. Tujuan pendidikan nasional tersebut dalam Undang - undang Nomor 20 tahun 2003 adalah mencerdaskan bangsa dan mengembangkan manusia seutuhnya, yaitu manusia Indonesia seutuhnya yang beriman dan bertaqwa kepada Tuhan Yang Maha Esa dan berbudi luhur, memiliki pengetahuan dan ketrampilan, kesehatan jasmani dan rohani, kepribadian yang mantap dan mandiri serta tanggung jawab kemasyarakatan dan kebangsaan ${ }^{2}$.

\footnotetext{
${ }^{2}$ Undang - undang Nomor 20 tahun 2003
} 
Peningkatan mutu pendidikan merupakan sasaran pembangunan di bidang pendidikan nasional dan merupakan bagian integral dari upaya peningkatan kualitas manusia Indonesia yang kaffah (menyeluruh). Kondisi pergulatan global yang mendunia, pendidikan nasional saat ini dihadapkan pada permasalahan hubungan yang tidak linier antara pendidikan dan dunia kerja. Perkembangan dunia kerja tidak terkejar oleh dunia pendidikan.

Salah satu komponen keberhasilan dalam dunia pendidikan adalah adanya tenaga pengajar yang disebut dengan guru,Guru merupakan salah satu orang yang melakukan perintah Allah amar ma'ruf nahi munkar. sebagaiamana disebut dalam surah Al-Imran $104^{3}$, disamping itu juga guru sebagai pemegang amanah, Sebagai pemegang amanat, guru bertanggung jawab atas amanah yang diserahkan kepadanya. Allah SWT menjelaskan dalam surah An-Nisa 58:

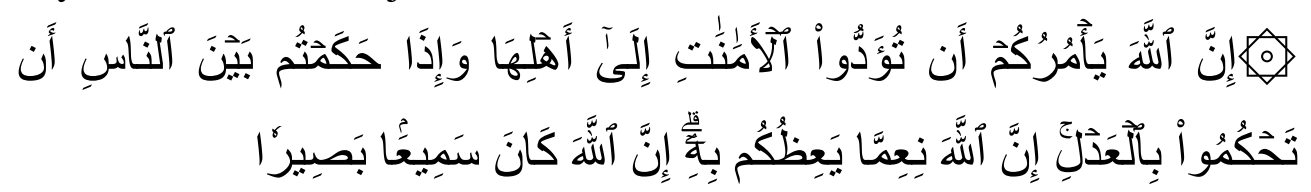

Artinya: Sesungguhnya Allah menyuruh kamu menyampaikan amanat kepada yang berhak menerimanya, dan (menyuruh kamu) apabila menetapkan hukum di antara manusia supaya kamu menetapkan dengan adil. Sesungguhnya Allah memberi pengajaran yang sebaik-baiknya kepadamu. Sesungguhnya Allah adalah Maha mendengar lagi Maha Melihat.

Standar kualifikasi akademik dan kompetensi guru telah dijelaskan berbagai kompetensi guru sesuai bidang mata pelajarannya masing-masing untuk meningkatkan kualitas mutu pendidikan ${ }^{4}$.Empat komponen penting dalam pendidikan yang saling terkait satu sama lain yaitu: a) kurikulum , yaitu materi yang akan diajarkan, b) proses yaitu bagaimana materi diajarkan, c) fasilitas yaitu berkaitan dengan sarana dan prasarana pendukung, d) produk yaitu hasil dari

${ }^{3} \mathrm{Al}-\mathrm{Qur}$ 'an Ali-Imran “ Dan hendaklah ada di antara kamu segolongan umat yang menyeru kepada kebajikan, menyuruh kepada yang ma'ruf dan mencegah dari yang munkar, merekalah orang-orang yang beruntung.

${ }^{4}$ Permendiknas No 16 Tahun 2007 
proses pendidikan). semua aspek ini sama pentingnya karena merupakan satu kesatuan yang membentuk lingkungan pendidikan.

Pembangunan pendidikan bukan hanya terfokus pada penyediaan faktor input pendidikan tetapi juga harus lebih memperhatikan proses pendidikan. Input pendidikan merupakan hal yang mutlak harus ada dalam batas-batas tertentu tetapi tidak menjadi jaminan dapat secara otomatis meningkatkan mutu pendidikan (school resources are necessary but not sufficient condition to improve student achievement).

Berdasarkan latar belakang di atas maka perlu adanya kajian masalah manajemen peningkatan mutu dalam pendidikan, dalam hal ini berkaitan dengan mutu pendidikan agama islam yang terdapat disekolah Umum, untuk itu penulis menulis tulisan yang berjudul "Studi Pada Pengendalian Mutu Pendidikan Agama Islam di SMAN 1 LABUHAN HAJI Lombok Timur".

\section{METODE PENELITIAN}

Fokus penelitian adalah pengendalian mutu pendidikan agama Islam di SMAN 1 Labuhan Haji Lombok Timur. Untuk menjawab fokus penelitian tersebut dibutuhkan subfokus yang mempertanyakan bagaimana instrumen yang digunakan dalam pengendalian mutu pendidikan agama Islam, sistem pengukuran serta sistem perbaikan mutu terhadap perkembangan pendidikan di SMAN 1 Labuhan Haji Lombok Timur. Fokus penelitian yang demikian terbentuk eksplanatori dan menurut Robert K. Yin lebih mengarah ke penggunaan studi kasus.

Penelitian ini menggunakan pendekatan kualitatif dengan rancangan atau desain studi kasus. Alasan digunakannya pendekatan penelitian ini adalah karena peneliti melihat sifat dari masalah yang dapat berkembang secara alamiah sesuai dengan kondisi dan situasi lapangan. Peneliti juga berkeyakinan bahwa dengan pendekatan alamiah, penelitian ini menggunakan informasi yang lebih banyak. Rancangan penelitian ini menggunakan pendekatan kualitatif, umumnya bersifat lebih banyak memperhatikan teori substantif dari data empiris yang akan didapat dilapangan. 


\section{PEMBAHASAN}

Setiap ummat muslim pada hakikatnya adalah insan agama yang bercitacita dan berpikir, beramal untuk hidup akhiratnya berdasarkan atas petunjuk dari wahyu Allah SWT melalui Rasulullah SAW.. Kesemuanya ini telah diwujudkan dalam syariat agama Islam berdasrkan nilai-nilai mutlak dan norma - normanya telah ditetapkan oleh Allah SWT.

Adapun Peran pendidikan agama Islam dalam kehidupan sehari-hari :

\section{Pendidikan agama Islam memberikan bimbingan dalam kehidupan}

Pengendalian utama kehidupan adalah kepribadiannya mencakup segala unsur-unsur pengamalan keagamaan dan keyakinan di dapatnya sejak kecil. Agama yang ditanamkan sejak kecil pada anak-anak merupakan bagian dari unsur-unsur kepribadiannya, akan cepat bertindak menjadi pengendali dalam menghadapi segala keinginan dan dorongan yang timbul. Karena keyakinan terhadap agama akan menjadi bagian kepribadiannya itu akan mempengaruhi sikap dan tingkah laku seseorang secara otomatis dari dalam.

\section{Pendidikan agama Islam adalah penolong dalam kesukaran}

Kesukaran yang sering dihadapi oleh seseorang adalah kekecewaan atau kegoncangan. Apabila kekacauan terlalu sering dihadapi dalam hidup ini, perasaan yang tidak berdaya dan penderitaan yang dialaminya menjadikan seseorang tersebut berpaling kepada Tuhan sebagai satu-satunya pegangan hidup. Dengan begitu yang dibutuhkan adalah keimanan kepada Tuhan dan pendekatan kepada Tuhan sehingga akan memiliki kepercayaan diri dan menghindari dari kesukaran yang dialaminya.

\section{Pendidikan agama Islam sebagai pengendali moral.}

Pembentukan dan perkembangan suatu sistem moral pribadi sejalan dengan pertumbuhan pengamalan keagamaan individu melalui kesadaran beragama dan pengalaman keTuhanan, ia akan menemukan kepribadiannya, ia pun akan menemukan prinsip dan norma pegangan hidupnya. Kesadaran agama itulah menjadi otonom, subjektif dan mandiri sehingga sikap dan tingkah laku merupakan pencerminan keadaan dirinya dalam penampilan dan kepribadiannya yang mantap. 
Strategi Pengendalian Mutu Pendidikan Agama Islam Di SMAN 1 Labuhan Haji Lombok Timur

Pembentukan nilai-nilai keagamaan atau religusitas sangat diutamakan untuk meningkatkan nilai moral dan sikap siswa-siswi SMAN 1 Labuhan Haji Lombok Timur. Sehingga strategi pengendalian mutu pendidikan Islam di SMAN 1 Labuhan Haji Lombok Timur yaitu dapat dilihat pada proses pengendalian kelas yang dikembangkan oleh tim pengembang mutu, dari flowchart dapat dipahami berbagai usaha untuk meningkatkan mutu pendidikan. Selain itu juga dalam proses peningkatan iman dan taqwa yang dilakukan oleh seluruh Bapak-Ibu guru pada siswa-siswi SMAN 1 Labuhan Haji Lombok Timur yaitu melalui pembiasaan, keteladanan, refleksi diri. 


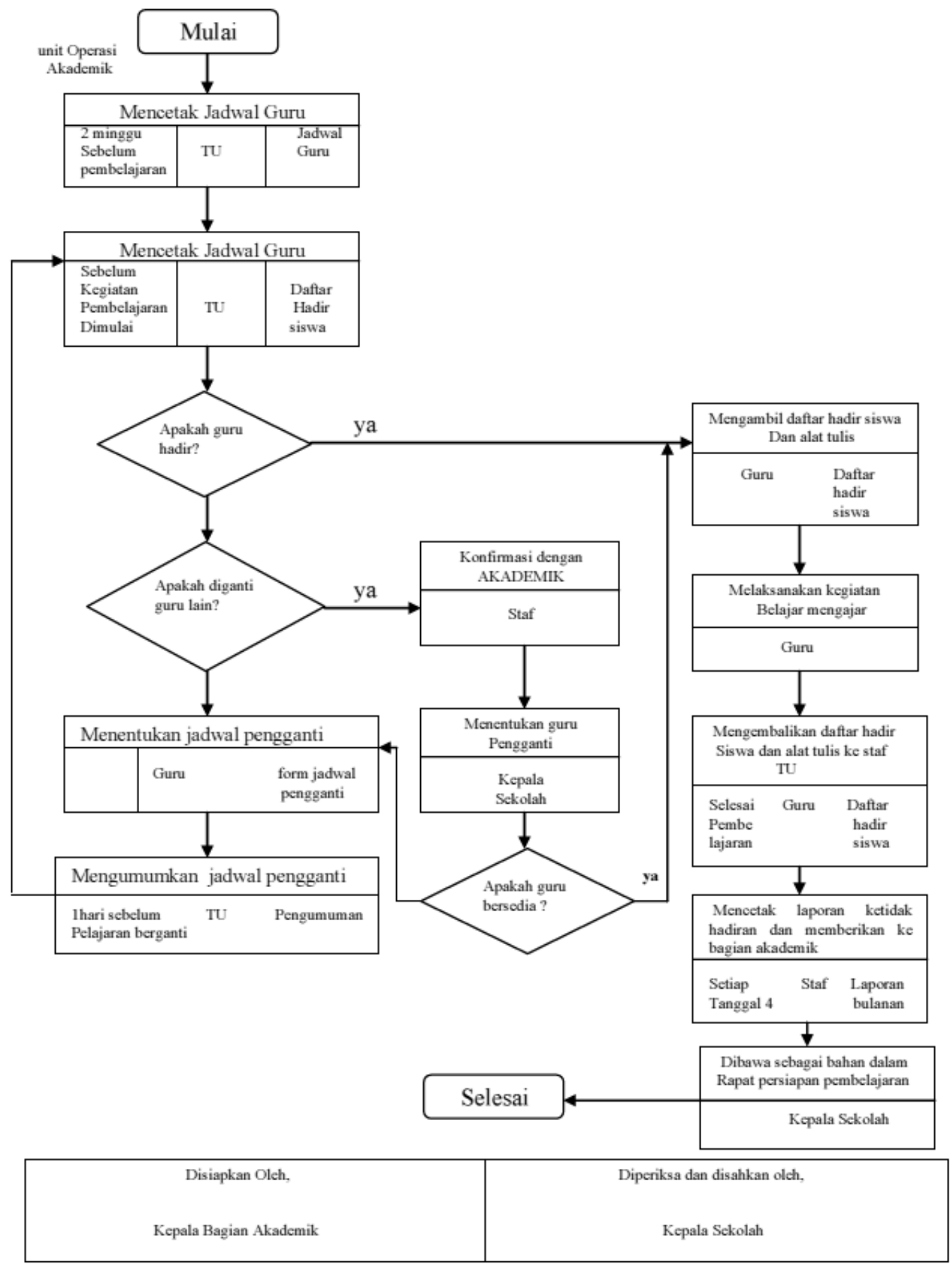

Sumber daya sekolah harus mempunyai fleksibilitas dalam mengatur semua sumber daya sesuai dengan kebutuhan setempat. Selain pembiayaan operasional atau administrasi, pengelolaan keuangan harus ditujukan untuk :

1. Memperkuat sekolah dalam menentukan dan mengalokasikan dana sesuai dengan skala prioritas yang telah ditetapkan untuk proses peningkatan mutu. 
2. Pemisahan antara biaya yang bersifat akademis dari proses pengadaannya.

3. Pengurangan kebutuhan birokrasi pusat.

Pertanggung-jawaban (accountability), sekolah dituntut untuk memilki akuntabilitas baik kepada masyarakat maupun pemerintah. Hal ini merupakan perpaduan antara komitmen terhadap standar keberhasilan dan harapan atau tuntutan orang tua dan masyarakat. Pertanggung-jawaban (accountability) ini bertujuan untuk meyakinkan bahwa dana masyarakat dipergunakan sesuai dengan kebijakan yang telah ditentukan dalam rangka meningkatkan kualitas pendidikan dan jika mungkin untuk menyajikan informasi mengenai apa yang sudah dikerjakan. Untuk itu sekolah harus memberikan laporan pertanggung-jawaban dan mengkomunikasikannya kepada orang tua dan pemerintah, dan melaksanakan kaji ulang secara komprehensif terhadap pelaksanaan program prioritas sekolah dalam proses peningkatan mutu.

Kurikulum, berdasarkan kurikulum standar yang telah ditentukan secara nasional, sekolah bertanggung jawab untuk mengembangkan kurikulum baik dari standar materi (content) dan proses penyampaiannya. Melalui penjelasan bahwa materi tersebut ada manfaat dan relevansinya terhadap siswa, madrasah harus menciptakan suasana pendidikan bermutu serta menyenangkan dan melibatkan semua indera dan lapisan otak serta menciptakan tantangan agar siswa tumbuh dan berkembang secara intelektual dengan menguasai ilmu pengetahuan, terampil, memilliki sikap arif dan bijaksana, karakter dan memiliki kematangan emosional.

Ada tiga hal yang harus diperhatikan dalam kegiatan ini yaitu: (1) Pengembangan kurikulum tersebut harus memenuhi kebutuhan siswa. (2) Bagaimana mengembangkan keterampilan pengelolaan untuk menyajikan kurikulum tersebut kepada siswa sedapat mungkin secara efektif dan efisien dengan memperhatikan sumber daya yang ada. (3) Pengembangan berbagai pendekatan yang mampu mengatur perubahan sebagai fenomena alamiah di sekolah.

Kwalitas keagamaan seseorang tidak hanya ditentukan oleh prestasi pendidikannya dalam bidang pendalaman agama Islam atau juga pengetahuannya tentang ajaran Islam, tetapi juga ditentukan oleh pengamalan mereka terhadap 
ajaran agama dalam kehidupan sehari-hari. Sesuai dengan hasil penulis yang ditemui dilapangan, pengamalan keagamaan siswa di SMAN 1 Labuhan Haji Lombok Timur sudah baik dalam bidang syariah aqidah dan akhlak, dan hasil observasi yaitu dapat dilihat pada waktu siswa menjalankan ibadah, mengikuti kegiatan disekolah seperti kegiatan ekstrakurikuler, pesantren kilat, sikap siswa terhadap guru dan teman-temannya, dan lain sebagainya. Meskipun ada beberapa siswa yang kurang dalam mengamalkan.

Pelaksanaan proses kegiatan pendidikan agama Islam di SMAN 1 Labuhan Haji Lombok Timur, dapat dikatakan normal dan berjalan sebagaimana mestinya. Artinya, mekanisme pendidikan, administrasi yang berkenaan dengan pendidikan agama Islam sudah kondusif. Sekalipun sedikit ada hal yang kurang mendukung terhadap jalannya proses pendidikan, misalnya kurang kedisiplinan sebagian kecil para staf-staf administrasi. Namun dari sebagian besar para guru di SMAN 1 Labuhan Haji Lombok Timur menyadari bahwa hal itu kurang begitu banyak berpengaruh ketika proses pendidikan berlangsung. Akan tetapi guru mempunyai persepsi, bahwa pasif tidaknya sebuah ruangan atau kelas gurulah yang memainkannya dengan menciptakan lingkungan yang aktif.

\section{Sistem Pengukuran Mutu Pendidikan Agama Islam di SMAN 1 Labuhan}

\section{Haji Lombok Timur}

. Beberapa pendekatan yang dilakukan oleh guru agama SMAN 1 Labuhan Haji Lombok Timur dalam pengendalian mutu pendidikan agama Islam yaitu sebagai berikut :

\section{Pendekatan Individu}

Pendekatan individual dalam proses kegiatan pendalaman nilai-nilai agama dalam kehidupan sehari-hari selalu dilakukan . Bila tidak dilakukan, maka proses pendidikan tidak dapat diharapkan kepada anak didik dengan tingkat penguasaan yang optimal. 


\section{Pendekatan Kelompok.}

Dengan pendekatan kelompok, guru dapat membina, mengarahkan, dan mengendalikan rasa egois yang ada dalam diri mereka masing - masing sehingga terbina sikap kesetiakawanan di kelas.

\section{Pendekatan edukatif}

Ada beberapa bentuk-bentuk motivasi diberikan agar siswa mampu mengamalkan serta menambah keimanan dan ketakwaan siswa atas kebesaran Allah SWT selalu mensyukuri segala kenikmatan yang telah dilimpahkan Allah SWT kepada mereka. Adapun upaya-upaya guru agama Islam untuk membina perilaku dalam pengamalan pendidikan Islam di SMAN 1 Labuhan Haji Lombok Timur yaitu sebagai berikut : Pertama, Mengarahkan anak didik dengan ibadah. Salah satu cara guru agama Islam untuk menggugah hati siswa rajin dalam melaksanakan ibadah hubungannya dengan Tuhan (seperti shalat, puasa dan lainlain) atau ibadah dalam hubungan dengn manusia (seperti menghormati orang tua, guru, teman dan lain-lain) adalah dengan cara memberikan nasihat atau ceramah yang diberikan pada waktu kegiatan pendidikan agama Islam.

Kedua, Mengarahkan siswa dengan membaca kitab suci al-Qur'an. Peranan guru agama Islam dalam hal ini adalah dengan memberikan kegiatan tambahan atau mengadakan kegiatan ekstrakurikuler seperti kajian kitab suci alQur'an guru membimbinga cara membaca al-Qur'an dan menulis arab dengan baik dan benar, serta membahas kandungan (arti) dari ayat tersebut diantaranya berisi tentang hukum hukum Islam (perintah dan larangan) sehingga siswa mengetahui kandungan dari ayat tersebut

Ketiga, Mengarahkan siswa dengan berdzikir kepada Allah SWT. Membiasakan siswa untuk berdzikir merupakan penunjang untuk meningkatkan kwalitas akhlaknya kepada Allah SWT dan banyak berdzikir juga dapat melebur dosa yang pernah diperbuat oleh manusia selama hidup di dunia. Keempat, Mewajibkan siswa untuk mengikuti kegiatan sholat berjama'ah di musholla SMAN 1 Labuhan Haji Lombok Timur. Mewajibkan siswa untuk membiasakan pergi ke musholla untuk shalat berjama'ah akan menambah keimanan dan keyakinannya kepada Allah SWT dan secara tidak langsung dalam diri siswa akan 
tumbuh rasa kasih sayang terhadap sesama yang dapat mempererat ukhuwah islamiyah.

Kelima, Mengarahkan siswa dengan amalan sunnah. Mengarahkan siswa dengan amalan sunnah adalah membiasakan siswa untuk melakukan amalan tambahan selain fardhu antara lain : (1) Berkaitan dengan ibadah shalat sunnah yaitu : shalat rawatib, dhuha, shalat hajat dan lain-lain. Tujuan diberikannya materi tambahan tersebut agar siswa mampu menerangkannya dalam kehidupan sehari-hari, mengarahkan siswa dengan amalan sunah merupakan implementasi dari pendidikan agama Islam. (2) Berkaitan dengan ibadah-ibadah puasa, misalnya puasa Senin Kamis, puasa enam hari dibulan syawal, puasa arafah dan masih banyak lagi.

Dengan mengarahkan siswa untuk melaksanakan ibadah sunnah ini, maka siswa akan mampu mengendalikan nafsunya untuk tidak berperilaku yang menyimpang seperti, merokok, berkelahi karena mereka pada umumya tahu fungsi dari puasa yaitu mencegah diri dari perbuatan keji dan kotor.

Sebagai lembaga pendidikan formal, SMAN 1 Labuhan Haji Lombok Timur secara umum memiliki tiga tanggung jawab yang mendasar, yaitu (1) Tanggung jawab formal, di mana kelembagaan formal kependidikan sesuai dengan fungsi, tugas, dan tujuan yang hendak dicapainya. (2) Tanggung jawab keilmuan, yaitu tanggung jawab berdasarkan bentuk, isi dan tujuan, serta tingkat pendidikan yang dipercayakan masyarakat kepadanya. (3) Tanggung jawab fungsional, yaitu bentuk tanggung jawab yang diterima sebagai pengelola fungsional dalam melaksanakan pendidikan oleh para pendidik yang diserahi kepercayaan dan tanggung jawab melaksanakannya dengan ketentuan yang berlaku sebagai pelimpahan wewenang dan kepercayaan serta tanggung jawab yang diberikan oleh orang tua peserta didik.

Adapun upaya pemecahannya dari pihak kepala SMAN 1 Labuhan Haji Lombok Timur dan guru dalam meningkatkan pengamalan keagamaan siswa yaitu : Pertama. Kepala sekolah dan para guru SMAN 1 Labuhan Haji Lombok Timur selalu memberi pengarahan kepada siswa-siswi baik pada waktu upacara hari Senin dan pada waktu kegiatan pendidikan di sekolah maupun diluar sekolah. 
Kedua. Pihak kepala SMAN 1 Labuhan Haji Lombok Timur untuk mengumpulkan para wali murid untuk diberikan pengarahan agar memperhatikan anak-anaknya dalam bidang ibadah, bergaul dan belajarnya, yang biasanya dilakukan pada waktu pengembalian raport murid. Ketiga, Adanya kerja sama dari pihak guru bagian pembinaan siswa dan wali kelas dalam menyelasaikan kasuskasus kenakalan yang terjadi dengan memberikan pengarahan dan nasehat pada anak yang bersangkutan tetapi apabila sifat dan kenakalan tersebut dianggap serius maka guru BP bersurat kepada orang tua murid.

\section{Implikasi Teoritis}

Pendidikan agama Islam merupakan suatu upaya yang terstruktur untuk membentuk manusia yang berkarakter sesuai dengan konsekuensinya sebagai seorang muslim. Dalam perjalanannya ada tiga jalan yang harus ditempuh untuk mengupayakan hal tersebut, yaitu: Pertama, Penanaman akidah Islam berdasarkan pemikiran yang matang dan dijalankan dengan cara yang damai. Kedua, Menanamkan sikap konsisten pada orang yang sudah memiliki akidah Islam agar segala tindak tanduk dan cara berpikirnya tetap berada di jalurnya sebagai seorang muslim. Ketiga, Mengembangkan kepribadian Islam pada mereka yang sudah memilikinya dengan cara mengajaknya untuk bersungguh-sungguh menjalankan kehidupan secara islami, dalam artian semua pemikiran dan amalannya sesuai dengan kodratnya sebagai seorang muslim.

\section{SIMPULAN}

Dari pembahasan ini Penulis dapat menarik kesimpulan bahwa Strategi pengendalian mutu pendidikan agama islam di SMAN 1 Labuhan Haji Lombok Timur yaitu pertama dari flowchart dapat dipahami bahwa pengendalian mulai dari kehadiran tenaga pendidik sampai keaktifan siswa melaksanakan program sekolah. Kedua kondisi alamiah total sumber daya yang tersedia dan prioritas untuk melaksankan program. Ketiga pelaksanaan konsep sekolah, membuat skala prioritas yang mengacu kepada program-program kegiatan pendidikan bagi siswa.

Sementara persetujuan dari proses pendanaan bukan semata-mata berdasarkan pertimbangan keuangan melainkan merefleksikan kebijakan dan prioritas tersebut, Sistem pengukuran mutu pendidikan agama Islam di SMAN 1 
Labuhan Haji Lombok Timur dilakukan memalui cara yaitu pertama melihat indikator mutu yang telah direncanakan misalnya dalam pengembangan potensi dan kepribadian siswa-siswi di SMAN 1 Labuhan Haji Lombok Timur banyak dilaksanakan dalam bentuk kegiatan ekstrakurikuler. Kedua menempatkan nilainilai agama dan budaya luhur bangsa sebagai spirit atau kekuatan dalam proses pengelolaan dan kegiatan pendidikan. Hal ini ditunjukkan antara lain dengan mengintegrasikan wawasan keagamaan pada kurikulum pendidikan SMAN 1 Labuhan Haji Lombok Timur . Ketiga dalam proses peningkatan iman dan taqwa dilakukan oleh seluruh Bapak-Ibu guru pada siswa-siswi SMAN 1 Labuhan Haji Lombok Timur yaitu melalui pembiasaan, keteladanan, refleksi diri.

\section{SARAN}

Adapun saran penulis sebagaiamana paparan berikut, yaitu: Setiap kegiatan pendidikan di SMAN 1 Labuhan Haji harus memiliki perencanaan yang jelas dan realisitis, pengorganisasian yang efektif dan efisien, pengerahan dan pemotivasian seluruh personil SMAN 1 Labuhan Haji untuk selalu dapat meningkatkan kualitas kinerjanya, dan pengawasan secara berkelanjutan. selanjutnya Memberikan support atau motivasi kepada anak didik untuk selalu kreatif dan inovatif dalam segala hal, agar mereka selalu percaya diri, sehingga mereka mampu menampakkan potensi dirinya dengan maksimal tanpa ada rasa takut, Menjaga kedisiplinan merupakan ujung tombak dalam sebuah kesuksesan terutama sebagai panutan terhadap anak didik dalam kesehariannya.

\section{DAFTAR PUSTAKA}

Anwar Arifin. 2003. Memahami Paradigma Baru Pendidikan Dalam UndangUndang Sisdiknas. Jakarta: Departemen Agama RI.

Abudin Nata. 2003. Manajemen Pendidikan Mengatasi Kelemahan Pendidikan Islam. Jakarta: Kencana.

Abdul Majid. 2006. Pendidikan Agama Islam Berbasis Kompetensi. Bandung: Remaja Rosda Karya.

Husaini Usman. 2006. Manajemen Pendidikan Teori, Praktik dan Riset

Pendidikan. Jakarta: Bumi Aksara. 
Hasan Langgulung. 2002. Peralihan Paradigma Pendidikan Islam dan Sains Sosial. Jakarta: Gaya Media Pratama.

Manan Idris, dkk. 2009. Aktualisasi Pendidikan Islam. Malang: UNM Press.

Permendiknas No 22 Tahun 2006. Standar Isi Pendidikan Agama Islam Sekolah Menengah Pertama. Jakarta: Rajawali Pers.

Suharsimi Arikunto. 2002. Prosedur Penelitian Suatu Pendekatan Praktek. Jakarta: PT Rineka Cipta. . 2000. Manajemen Penelitian. Jakarta: Rineka Cipta.

Syaiful Sagala. 2009. Manajemen Strategik Dalam Peningkatan Mutu Pendidikan. Bandung: Alfabeta. . 2009. Kemampuan Profesional Guru dan Tenaga Kependidikan. Bandung: Afabeta.

Umar Tirtarahardja. 2005. Pengantar Pendidikan. Jakarta: Rineka Cipta.

Undang-Undang Nomor 20 Tahun 2003 tentang Sistem Pendidikan Nasional. Jakarta..

Zakiyah Daradjah. 1987. Peranan Agama Dalam Kesehatan Mental. Jakarta: Gunung Agung. 